\title{
Identifikasi Staphylococcal Cassette Chromosome Mec Methicillin Resistant Staphylococcus aureus dengan Polymerase Chain Reaction
}

\author{
Yuwono, ${ }^{1}$ Sunarjati SA, ${ }^{2}$ Sadeli Masria, ${ }^{2}$ Imam Supardi ${ }^{2}$ \\ ${ }^{1}$ Departemen Mikrobiologi Fakultas Kedokteran Universitas Sriwijaya/Rumah Sakit Moh. Hoesin, \\ Palembang; ${ }^{2}$ Departemen Mikrobiologi Fakultas Kedokteran Universitas Padjadjaran- \\ Rumah Sakit Dr. Hasan Sadikin, Bandung
}

\begin{abstract}
Abstrak
Methicillin resistant Staphylococcus aureus (MRSA) merupakan salah satu galur multiresisten yang menjadi masalah kesehatan global sejak 50 tahun terakhir. Secara genetik, resistensi MRSA didasari adanya insersi mecDNA atau Staphylococcal cassette chromosome mec (SCCmec) pada kromosom S. aureus. Sejauh ini telah diidentifikasi 5 tipe SCCmec, yaitu SCCmec tipe I-V yang berasal dari isolat di seluruh dunia. Akhir-akhir ini ditemukan perubahan pola penyebaran, pola kepekaan terhadap antimikrob, dan perubahan kandungan SCCmec. Oleh karena itu identifikasi SCCmec menjadi demikian penting untuk mengetahui adanya perubahan tersebut. Tujuan penelitian ini adalah untuk mengidentifikasi tipe SCCmec dari isolat MRSA yang diperoleh di rumah sakit. Penelitian dilakukan di Laboratorium Mikrobiologi Klinik RSUP Moh. Hoesin Palembang dalam rentang waktu Oktober 2008-Maret 2009. Metode yang digunakan untuk mengidentifikasi SCCmec tersebut adalah metode polymerase chain reaction (PCR) multipleks. Hasil penelitian menunjukkan bahwa 33 isolat (83\%) memiliki SCCmec tipe III dan 7 isolat (17\%) memiliki SCCmec tipe IV. Hasil ini berbeda dengan penelitian sebelumnya yang menemukan 100\% MRSA di Indonesia memiliki SCCmec tipe III. Kesimpulan dari penelitian ini adalah teridentifikasi adanya perubahan kandungan SCCmec pada isolat MRSA yang berasal dari rumah sakit.
\end{abstract}

[MKB. 2011;43(2):60-5].

Kata kunci: Methicillin resistant Staphylococcus aureus, polymerase chain reaction, SCCmec

\section{Identification of Staphylococcal Cassette Chromosome Mec Methicillin Resistant Staphylococcus aureus Using Polymerase Chain Reaction}

\begin{abstract}
Methicillin resistant Staphylococcus aureus (MRSA) is one of multiresistant strain that becomes global health problem during 50 years. Resistance of MRSA is based on insertion mobile genetic element mecDNA or Staphylococcal cassette chromosome mec ( $\mathrm{SCCmec}$ ) into chromosome of $S$. aureus. Researchers had been isolated five types of SCCmec-type i.e. I-V. During last ten years, researchers have been finding alteration of spreading pattern, susceptibility pattern, and content of SCCmec. Identification of SCCmec is important to elucidate these alterations. The aim of this research was to identify type of SCCmec from hospital isolates MRSA.We did the research in Moh. Hoesin General Hospital (RSUP MH) Palembang period October 2008 to March 2009. We used polymerase chain reaction (PCR) multiplex method to identify SCCmec. The result showed that 33 isolates $(83 \%)$ having type III of SCCmec and 7 isolates (17\%) having type IV of SCCmec. The results were different from other researcher's founding that in Indonesia, all of MRSA have SCCmec. The conclusion of this research content of SCCmec from hospital isolates of MRSA has already been changed. [MKB. 2011;43(2):60-5].
\end{abstract}

Key words: Methicillin resistant Staphylococcus aureus, polymerase chain reaction, SCCmec

Korespondensi: Dr. Yuwono, dr., M. Biomed, Departemen Mikrobiologi Fakultas Kedokteran Universitas Sriwijaya/Rumah Sakit Moch. Hoesin, jalan Dr. Moh. Ali Komp. RSMH Km. 3,5 Palembang, telepon (0711) 373438, mobile 08127115678, e-mail:masyon@doctor.com 


\section{Pendahuluan}

Methicillin resistant Staphylococcus aureus (MRSA) atau healthcare associated MRSA (HA-MRSA) ditemukan pertama kali di Inggris oleh Jevons pada tahun 1961. Bakteri penyebab infeksi nosokomial ini bersifat multiresisten, yaitu kebal terhadap semua jenis antimikrob golongan betalaktam dan terhadap lebih dari 2 macam antimikrob nonbetalaktam. ${ }^{1}$ Spektrum infeksi yang ditimbulkan oleh MRSA bersifat sangat luas, yaitu mulai dari infeksi kulit yang ringan hingga infeksi berat seperti endokarditis dan sepsis. ${ }^{2}$ Sejauh ini dilaporkan hanya vankomisin yang masih peka terhadap MRSA. Infeksi oleh MRSA mencapai 30-70\% dari seluruh infeksi $S$. aureus di rumah sakit di seluruh dunia. ${ }^{3}$

Pada tahun 1998 di Amerika Serikat dilaporkan adanya galur baru yang diberi nama communityassociated MRSA (CA-MRSA) yang bersifat nonmultiresisten, yaitu hanya kebal terhadap antimikrob betalaktam. Sebagian ahli menduga CAMRSA merupakan turunan HA-MRSA, sedangkan sebagian lain menduga bahwa CA-MRSA merupakan galur tersendiri yang terbentuk secara alami di luar lingkungan rumah sakit. ${ }^{4}$

Resistensi MRSA terhadap berbagai antimikrob diperankan oleh dua kelompok gen, yaitu kelompok gen utama yang berperan mendasari resistensi terhadap antimikrob betalaktam dan kelompok gen lainnya yang berperan mendasari resistensi terhadap antimikrob nonbetalaktam. Resistensi MRSA terhadap antimikrob betalaktam terjadi karena adanya duplikasi pada penicillin binding protein (PBP), yaitu PBP2 dan PBP2a. Fungsi PBP2 yang terhenti karena pemberian betalaktam akan dikompensasi oleh PBP2a sehingga sintesis dinding sel pada MRSA tetap berlangsung. ${ }^{5}$ Resistensi MRSA terhadap antimikrob nonbetalaktam terutama terjadi karena adanya perubahan pada molekul reseptor atau karena antimikrob dipompa secara aktif ke luar sel yang disebut mekanisme efflux. ${ }^{6}$

PBP2a disandi oleh gen mecA yang merupakan bagian conserved (terpelihara) dari elemen genetik yang disebut mecDNA atau Staphylococcal cassette chromosome mec (SCCmec). ${ }^{7}$ Gen mecA dan $\mathrm{SCC}$ ec tidak ditemukan pada galur S. aureus sensitif metisilin (methicillin sensitive Staphylococcus aureus/MSSA). Diduga gen mecA berasal dari Staphylococcus sciuri, sedangkan SCCmec diduga berasal dari Staphylococcus hominis. Berbagai bukti menunjukkan bahwa galur HA-MRSA memiliki salah satu di antara tiga tipe SCCmec, yaitu tipe I, II atau III, sedangkan galur CA-MRSA memiliki SCCmec tipe IV. ${ }^{8,9}$

Secara umum komponen penyusun SCCmec adalah gen rekombinase (kompleks $c c r$ ), gen kompleks mec, gen resisten tambahan, dan insertion sequence (IS). Perbedaan antar SCCmec ditentukan oleh variasi pada kompleks $\mathrm{ccr}$ dan kompleks mec. SCCmec tipe I berukuran sekitar $39 \mathrm{~kb}$, dominan pada era tahun 1960-an, memiliki komposisi kompleks $c c r$ tipe 1 dan kompleks mec kelas B. SCCmec tipe II berukuran sekitar $52 \mathrm{~kb}$, dominan pada era tahun 1980-an, memiliki komposisi kompleks ccr tipe 2 dan kompleks mec kelas A. SCCmec tipe III berukuran paling besar sekitar $67 \mathrm{~kb}$, juga dominan pada era tahun 1980an, memiliki komposisi kompleks $c c r$ tipe 3 dan kompleks mec kelas A. SCCmec tipe IV (a dan b) berukuran 20,9-24,3 kb, ditemukan sekitar tahun 2002, memiliki komposisi kompleks $c c r$ tipe 2 dan kompleks mec kelas B. ${ }^{10,11}$

Sejak ditemukannya CA-MRSA pada tahun 1998, terjadi perubahan pada gambaran antibiogram, kandungan SCCmec, dan distribusi MRSA di berbagai negara. Beberapa peneliti menemukan HAMRSA dengan gambaran antibiogram yang bersifat nonmultiresisten, sedangkan beberapa peneliti lainnya menemukan CA-MRSA dengan gambaran antibiogram yang multiresisten. Beberapa kelompok peneliti menemukan bahwa CA-MRSA multiresisten mendapat SCCmec yang berbeda dari biasanya, yaitu SCCmec tipe I atau II. Sejauh ini belum ditemukan CA-MRSA multiresisten dengan SCCmec tipe III. Hal ini kemungkinan disebabkan ukuran SCCmec III yang paling besar dibandingkan dengan tipe SCCmec lainnya, sehingga sangat sulit untuk berpindah. Para peneliti juga menemukan bahwa masing-masing galur MRSA mulai terdistribusi di luar lingkungan yang selama ini lazim sebagai habitatnya. Healthcare associated-MRSAtelah ditemukan danmenimbulkan infeksi di lingkungan masyarakat di luar rumah sakit dan sebaliknya CA-MRSA ditemukan di rumah sakit dan menimbulkan infeksi nosokomial. ${ }^{12,13}$

Berdasarkan uraian tersebut peneliti bermaksud melakukan kajian tentang tipe SCCmec pada isolat MRSA yang berasal dari rumah sakit. Sejauh ini data atau publikasi MRSA di Indonesia masih sangat terbatas. Tujuan penelitian ini adalah mengidentifikasi tipe SCCmec pada isolat MRSA rumah sakit dengan harapan agar dapat diketahui apakah telah terjadi perubahan pola kandungan SCCmec pada MRSA yang berasal dari rumah sakit. Temuan ini penting tidak hanya untuk masalah pengobatan dan pengendalian infeksi MRSA, tetapi juga untuk mengetahui distribusi genetik galur tersebut.

\section{Metode}

Sebanyak 40 isolat MRSA didapat dari beberapa rumah sakit dan laboratorium di Bandung. Isolat tersebut dibiakkan dan diidentifikasi sebagai $S$. aureus resisten metisilin di Laboratorium Mikrobiologi FK Unpad-Rumah Sakit Dr. Hasan Sadikin Bandung periode Januari-September 2008. Isolat tersebut 
dibawa ke Laboratorium Mikrobiologi FK Unsri/ RSMH Palembang untuk dilakukan biakan ulang dan uji kepekaan terhadap antimikrob atau untuk diidentifikasi ulang sebagai MRSA berdasarkan gambaran fenotip. Galur kontrol sensitif adalah $S$. aureus ATTC 25923 yang diperoleh dari Balai Besar Laboratorium Kesehatan Palembang. Penelitian dilakukan periode Oktober 2008-Maret 2009.

Isolasi $S$. aureus menggunakan media agar darah diinkubasi 24 jam pada suhu $37^{\circ} \mathrm{C}$, kemudian dilakukan identifikasi dengan pewarnaan Gram dan uji koagulase untuk membedakan dengan koagulase negatif staphylococcus (CoNS). Uji kepekaan terhadap antimikrob menggunakan metode difusi cakram pada media agar Mueller Hinton (MH). Kekeruhan inokulum dibandingkan dengan turbidity standard 0,5 Mc.Farland. Suspensi bakteri tersebut diratakan pada permukaan agar Muller Hinton dan setelah menunggu 5 menit diletakkan cakram metisilin $5 \mu \mathrm{g}$, selanjutnya diinkubasi 36 jam pada suhu $30^{\circ} \mathrm{C}$. Selain cakram metisilin juga digunakan cakram antimikrob betalaktam lainnya, yaitu penisilin 10 unit dan ampisilin $10 \mu \mathrm{g}$ serta beberapa cakram antimikrob nonbetalaktam, yaitu eritromisin $15 \mu \mathrm{g}$, norfloksasin $10 \mu \mathrm{g}$, gentamisin $10 \mu \mathrm{g}$, dan vankomisin $30 \mu \mathrm{g}$. Diameter zona hambat diukur dengan caliper dalam skala milimeter. Interpretasi hasil uji kepekaan dilakukan dengan melihat nilai diameter zona hambat sesuai protokol NCCLS tahun 2000. ${ }^{14,15}$ Diameter zona hambat merupakan discriminatory antimicrobial concentrations yang digunakan untuk menentukan apakah isolat yang diperiksa termasuk sensitif (peka) (S), intermediate (I), atau resisten (R). Breakpoints untuk antimikrob tersebut terlihat pada Tabel 1.

Ekstraksi DNA dilakukan dengan modifikasi chelex resin DNA extraction, yaitu lima koloni bakteri dimasukkan ke dalam tabung mengandung phosphate buffer saline (PBS) $500 \mu \mathrm{L}$. Dilakukan sentrifugasi $5.000 \mathrm{rpm}$ selama 5 menit. Supernatan dibuang dan pellet yang didapat diresuspensi dengan lysis buffer, yaitu saponin. Selanjutnya diinkubasi dalam es selama 10 menit, kemudian disentrifugasi 12.000 rpm selama 10 menit. Ditambahkan $50 \mu \mathrm{L}$ chelex resin $20 \%$ dan $100 \mu \mathrm{L}$ akuades steril. Direbus dalam air mendidih selama 10 menit, kemudian disentrifugasi $12.000 \mathrm{rpm}$ selama 10 menit. DNA akan berada pada supernatan. Sebanyak 2-3 $\mu \mathrm{L}$ cairan mengandung DNA dapat digunakan sebagai template untuk polymerase chain reaction (PCR). ${ }^{15}$

Polymerase chain reaction multipleks pada penelitian ini menggunakan acuan yang pernah dilakukan oleh Zhang dkk. ${ }^{16}$ Rangkaian primer dan amplikon hasil PCR dapat dilihat pada Tabel 2.

Tabel 1 Diamaeter Zona Hambat Beberapa Antimikrob yang Digunakan pada Penelitian (Protokol NCCLS 2000)

\begin{tabular}{lccc}
\hline \multicolumn{1}{c}{ Antimikrob } & \multicolumn{2}{c}{ Breakpoints (diameter dalam milimeter/mm) } \\
\cline { 2 - 4 } & Sensitif (S) & Intermediat (I) & Resisten (R) \\
\hline Penisilin (PEN) & $\geq 29$ & - & $\leq 28$ \\
Oxacillin (OXA) & $\geq 13$ & $11-2$ & $\leq 10$ \\
Ampisilin (AMP) & $\geq 29$ & - & $\leq 28$ \\
Vankomisin (VAN) & $\geq 15$ & - & $\leq 14$ \\
Gentamisin (GEN) & $\geq 15$ & $13-14$ & $\leq 12$ \\
Eritromisin (ERI) & $\geq 23$ & $14-22$ & $\leq 13$ \\
Norfloksasin (NOR) & $\geq 17$ & $13-16$ & $\leq 12$ \\
\hline
\end{tabular}

Keterangan: Tanda (-) berarti tidak ada nilai Intermediat (I), yang ada hanya S dan R

Tabel 2 Primer, Amplikon, dan Tipe SCCmec

\begin{tabular}{|c|c|c|c|}
\hline Primer & Sekuens Oligonukleotida (5'-3') & Amplikon & Spesifisitas \\
\hline $\mathrm{I}-\mathrm{F}$ & GCTTTAAAGAGTGTCGTTACAGG & \multirow{2}{*}{$613 \mathrm{bp}$} & \multirow{2}{*}{ SCCmec I } \\
\hline $\mathrm{I}-\mathrm{R}$ & GTTCTCTCATAGTATGACGTCC & & \\
\hline II-F & CGTTGAAGATGATGAAGCG & \multirow{2}{*}{$398 \mathrm{bp}$} & \multirow{2}{*}{ SCCmec II } \\
\hline II-R & CGAAATCAATGGTTAATGGACC & & \\
\hline III-F & CCATATTGTGTACGATGCG & \multirow{2}{*}{$280 \mathrm{bp}$} & \multirow{2}{*}{$\mathrm{SCCmec} \mathrm{III}$} \\
\hline III-R & CCTTAGTTGTCGTAACAGATCG & & \\
\hline IVa-F & GCCTTATTCGAAGAAACCG & \multirow{2}{*}{776 bp } & \multirow{2}{*}{ SCCmec IVa } \\
\hline IVa-R & CTACTCTTCTGAAAAGCGTCG & & \\
\hline $\mathrm{IVb}-\mathrm{F}$ & TCTGGAATTACTTCAGCTGC & \multirow{2}{*}{$493 \mathrm{bp}$} & \multirow{2}{*}{$\mathrm{SCCmec} \mathrm{IVb}$} \\
\hline $\mathrm{IVb}-\mathrm{R}$ & AAACAATATTGCTCTСССТC & & \\
\hline MecA147-F & GTG AAG ATA TAC CAA GTG ATT & \multirow{2}{*}{$147 \mathrm{bp}$} & \multirow{2}{*}{ mecA } \\
\hline MecA147-R & ATG CGC TAT AGA TTG AAA GGA T & & \\
\hline
\end{tabular}


Amplifikasi dilakukan dalam mesin i-cycler Biorad (Biorad System, USA) dimulai dengan denaturasi inisial $94^{\circ} \mathrm{C}$ selama 5 menit diikuti 10 siklus dengan suhu denaturasi $94^{\circ} \mathrm{C}$ selama 45 detik, suhu annealing $65^{\circ} \mathrm{C}$ selama 45 detik dan suhu ekstensi $72^{\circ} \mathrm{C}$ selama 90 detik, kemudian 25 siklus dengan suhu denaturasi $94^{\circ} \mathrm{C}$ selama 45 detik, annealing $55^{\circ} \mathrm{C}$ selama 45 detik, ekstensi $72^{\circ} \mathrm{C}$ selama 90 detik, diikuti ekstensi final $72^{\circ} \mathrm{C}$ 10 menit dan diakhiri pada suhu $4^{\circ} \mathrm{C}$. Untuk melakukan PCR dengan target tunggal misalnya hanya SCCmec tipe III, maka dilakukan dengan kondisi denaturasi inisial $94^{\circ} \mathrm{C}$ selama 5 menit diikuti 30 siklus dengan suhu denaturasi $94^{\circ} \mathrm{C}$ selama 1 menit, annealing $50^{\circ} \mathrm{C}$ selama 1 menit dan ekstensi $72^{\circ} \mathrm{C}$ selama 2 menit, serta ekstensi final $72^{\circ} \mathrm{C}$ selama 10 menit.

Volume total reaksi PCR adalah $25 \mu \mathrm{L}$ yang berisi 2,5 $\mu \mathrm{L}$ bufer, $1 \mu \mathrm{L} \mathrm{MgCl}, 0,5 \mathrm{mM}$ deoxynucleoside triphosphate (dATP, dUTP, dGTP, dan dCTP) (Invitrogen Inc., Carlsbad, CA), 0,5 $\mu \mathrm{L}$ masingmasing primer (tabel primer), $0,1 \mu \mathrm{L}$ Platinum Taq DNA polimerase (Invitrogen Inc., Carlsbad, CA), $11,9 \mu \mathrm{L}$ air steril dan $3 \mu \mathrm{L}$ template DNA.

Visualisasi pita hasil PCR multipleks dilakukan dengan cara elektroforesis pada $2 \%$ gel agarosa, $1 \mathrm{X}$ TAE, 80 volt, 400 mili ampere selama 20 menit, diwarnai dengan etidium bromida 10 $\mu \mathrm{g} / \mathrm{mL}$ dan difoto dengan Biorad Gel Doc (Biorad System, USA).

\section{Hasil}

Semua isolat (40 isolat) yang telah diidentifikasi sebagai $S$. aureus resisten metisilin memperlihatkan hasil PCR positif untuk gen mecA. Hal ini menunjukkan bahwa ternyata isolat tersebut adalah MRSA karena gen mecA merupakan gen conserved bagian dari SCCmec yang khas untuk galur MRSA. $S$. aureus sensitif tidak memiliki gen tersebut.

Hasil PCR multipleks menunjukkan 33 isolat atau $83 \%$ memiliki SCCmec tipe III dan 7 isolat atau $17 \%$ memiliki SCCmec tipe IV.

\section{Pembahasan}

Sebagian besar tipe SCCmec adalah tipe III. Hasil ini sesuai dengan penelitian yang dilakukan di 11

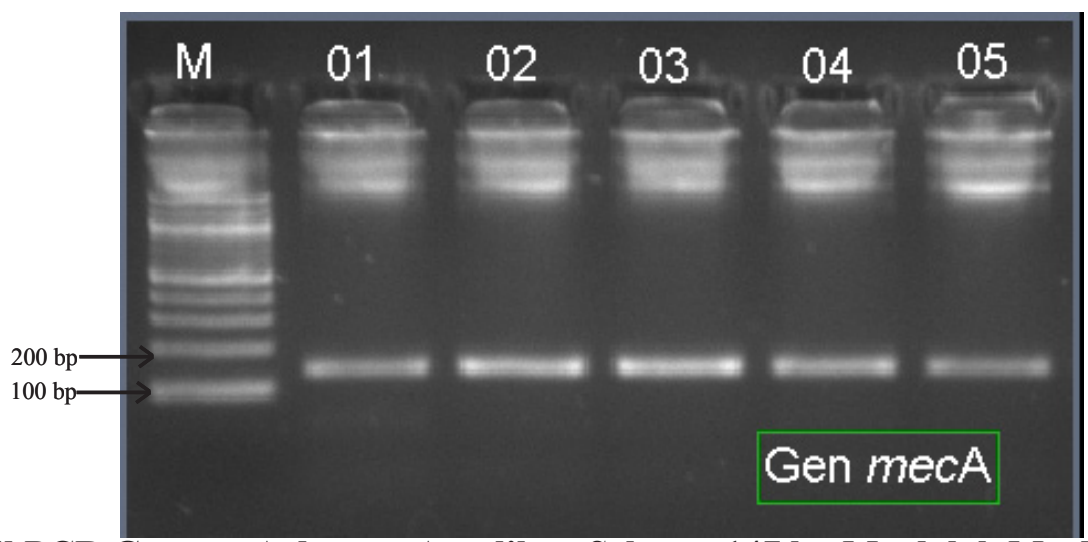

Gambar 1 Hasil PCR Gen mecA dengan Amplikon Sebesar 147 bp M adalah Marker DNA, Sampel pada Alur 01-05

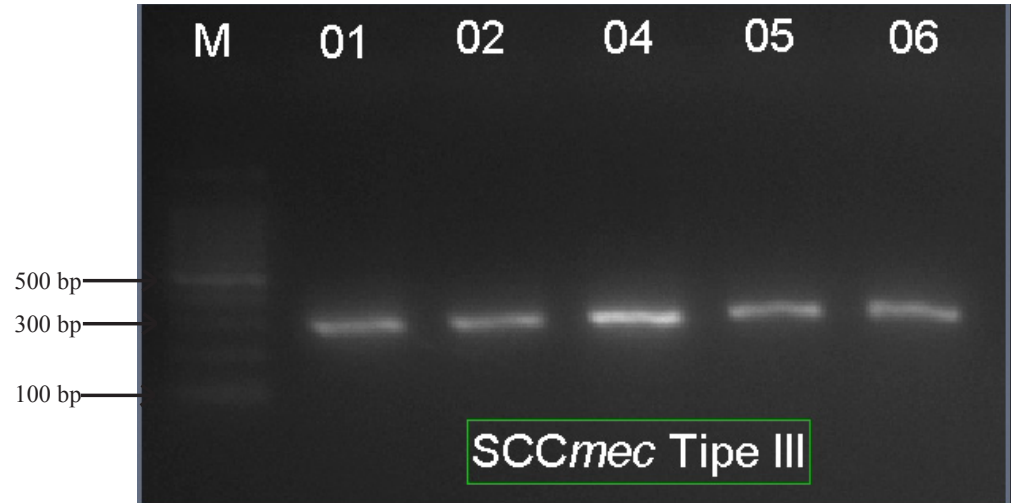

Gambar 2 Hasil PCR SCCmec Tipe III dengan Amplikon Sebesar 280 bp M adalah Marker DNA, Sampel pada Alur 01, 02, 04-06 


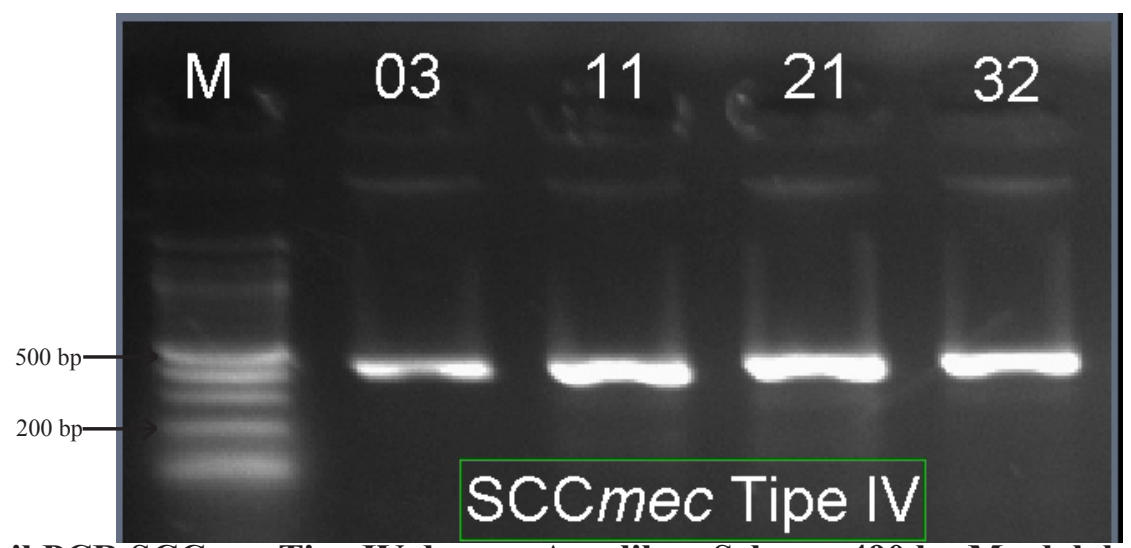

\section{Gambar 3 Hasil PCR SCCmec Tipe IV dengan Amplikon Sebesar 490 bp M adalah Marker DNA, Sampel pada Alur 03, 11, 21, 32}

negara di Asia termasuk sampel dari Indonesia. Bahkan pada penelitian tersebut, isolat dari Indonesia semua memiliki SCCmec tipe III. ${ }^{17}$ Hasil berbeda adalah pada penelitian ini ditemukan sebagian kecil isolat menunjukkan bahwa pada MRSA yang diisolasi dari rumah sakit telah ditemukan SCCmec tipe IV. Ini mengindikasikan telah terjadi pergeseran kandungan SCCmec pada isolat yang ada di Indonesia. Bila dikatakan bahwa isolat rumah sakit adalah CA-MRSA, berarti pada sebagian populasi galur tersebut telah terjadi pergeseran kandungan SCCmec. Dalam perspektif terapi dan pencegahan hal ini merupakan kabar buruk, karena seperti diketahui SCCmec tipe IV bersifat lebih mobile dan meskipun mendasari fenotip yang nonmultiresisten, tetapi menimbulkan spektrum klinis yang umumnya lebih berat dan tetap dengan pemilihan antimikrob yang sulit untuk terapinya. ${ }^{18}$

Berdasarkan hasil tersebut dapat disimpulkan bahwa pada MRSA di Indonesia telah ditemukan perubahan kandungan SCCmec. Saran untuk penelitian mendatang adalah dilakukan studi kohor dari sampel rumah sakit maupun populasi atau berobat jalan atau penderita puskesmas untuk mengumpulkan isolat MRSA, kemudian melakukan identifikasi tipe SCCmec dan hubungannya dengan pola kepekaan serta manifestasi klinisnya. ${ }^{19}$

\section{Daftar Pustaka}

1. Coombs GW, Nimmo GR, Bell JM, Huygens F, O'Brien FG, Malkowski MJ, dkk. Diversity among community methicillinresistant Staphylococcus aureus strains causing outpatient infections in Australia. J Clin Microbiol. 2004;42:4735-43.

2. Grayson ML. The treatment triangle for Staphylococcal infections. N Engl J Med. 2006;355:724.
3. Donnio PY, Fevrier F, Bifani P, Dehem M, Kervegant C, Wilhelm N, dkk. Molecular and epidemiological evidence for spread of multiresistant methicillin-susceptible Staphylococcus aureus in hospitals. Antimicrob Agents Chemother. 2007;50:1414-6.

4. Ma $X$, Ito $K$, Tiensasitorn $C$, Jamklang $M$, Chongtrakool P, Boyle VR, dkk. Novel type of staphylococcal cassette chromosome mec identified in community-acquired methicillin-resistant Staphylococcus aureus strains. Antimicrob Agents Chemother. 2002; 46:1147-52.

5. Fuda C, Suvorov M, Vakulenko SB, Mobashery $\mathrm{S}$. The basis for resistance to betalactam antibiotics by PBP2a of MRSA. J Biol Chem. 2004;279:40802-6.

6. Castellanos RG, Fernandez GM, Marrero A, Potempa J, Coll M, Ruth XG. On the transcriptional regulation of methicillin resistance. J Biol Chem. 2004;279:17888-96.

7. Arakere G, Nadig S, Swedberg G, Macaden R, Amarnath SK, Raghunath D. Genotyping of methicillin-resistant Staphylococcus aureus strains from two hospitals in Bangalore, South India. J Clin Microbiol. 2005;43:3198-202

8. Katayama Y, Takeuchi F, Ito T, Ma X, UiMizutani Y, Kobayashi I, dkk. Identification in methicillin-susceptible Staphylococcus hominis of an active primordial mobile genetic element for the Staphylococcal cassette chromosome mec of methicillinresistant Staphylococcus aureus. J Bacteriol. 2003; 185:2711-22.

9. Wu SW, de Lencastre H, Tomasz A. Recruitment of the mecA gene homologue of Staphylococcus sciuri into a resistance determinant and expression of the resistant phenotype in Staphylococcus aureus. J Bacteriol. 2001;183:2417-24. 
10. Gomes AR, Westh $H$, de Lencastre $H$. Origins and evolution of methicillin-resistant Staphylococcus aureus clonal lineages. Antimicrob Agents Chemother. 2006;50:323744.

11. Huang YC, Su LH, Wu TL, Lin TY. Changing molecular epidemiology of methicillinresistant Staphylococcus aureus bloodstream isolates from a teaching hospital in Northern Taiwan. J Clin Microbiol. 2006;44:2268-70.

12. Hsu LY, Koh TH, Singh K, Kang ML, Kurup A, Tan BH. Dissemination of multisusceptible methicillin-resistant Staphylococcus aureus in Singapore. J Clin Microbiol. 2005;43:2923-5.

13. Haque NZ, Speirs K, Muder RR, Robinson DB, Hayden MK, Zervos MJ. Epidemiology and outcomes of community-associated ethicillin-resistant Staphylococcus aureus infection. J Clin Microbiol. 2007;45:170511.

14. Smyth RW, Kahlmeter G. Mannitol salt agarcefoxitin combination as a screening medium for methicillin-resistant Staphylococcus aureus. J Clin Microbiol. 2005;43:3797-9.

15. Rosenthal A, White D, Churilla S, Brodie S, Katz KC. Optimal surveillance culture sites for detection of methicillin-resistant
Staphylococcus aureus in newborns. J Clin Microbiol. 2006;44:4234-6.

16. Zhang K, McClure J, Elsayed S, Louie T, Conly J. Novel multiplex PCR assay for characterization and concomitant subtyping of Staphylococcal cassette chromosome mec types I to $\mathrm{V}$ in methicillin-resistant Staphylococcus aureus. J Clin Microbiol. 2005;43:5026-33.

17. Chongtrakool $\mathrm{P}$, Ito $\mathrm{T}$, Ma $\mathrm{X}$, Kondo $\mathrm{Y}$, Trakulsomboon S, Tiensasitorn C, dkk. Staphylococcal cassette chromosome mec (SCCmec) typing of methicillin-resistant Staphylococcus aureus strains isolated in 11 Asian countries: a proposal for a new nomenclature for SCCmec elements. Antimicrob Agents Chemother. 2006;50:1001-2.

18. Tenover FC, McDougal LK, Goering RV, Killgore G, Projan SJ, Patel JB, dkk. Characterization of a strain of community-associated methicillin-resistant Staphylococcus aureus widely disseminated in the United States. J Clin Microbiol. 2006; 44:108-18

19. Wijaya L, Hsu L, Kurup A. CA-MRSA: overview and local situation. Annals Acad Med. 2006;35:476-85. 